\title{
Optimization of spray-drying conditions for obtaining Bacillus sp. SMIA-2 protease powder
}

\author{
Raphael PIRES BOLZAN ${ }^{1,2}$, Erica CRUZ ${ }^{2}$, João BATISTA BARBOSA ${ }^{3}$, Simone VILELA TALMA ${ }^{3}$, \\ Meire Lelis LEAL MARTINS ${ }^{2 *}$
}

\begin{abstract}
Microbial proteases, especially from Bacillus spp., have enormously been exploited for a broad variety of applications such as for physiological processes, food and feedstuff, detergents, as well as in the pharmaceutical and leather. In this work, proteases produced by the thermophilic Bacillus sp. SMIA-2 submerged cultures were spray-dried in an attempt to improve its stability for applications in industry. The enzymatic extract was dried using drying adjuvants, and optimal conditions for preserving enzymatic activity were studied following a statistical experimental design. The spray process factors studied were the drier air inlet temperature and the adjuvants concentrations. The responses analyzed were the enzymatic activity and mass recovered of the powder after spray drying. Additionally, the stability of the powder was assessed during 180 days at room temperature. The results revealed that satisfactory levels of enzymatic activity were obtained when $0.5 \%(\mathrm{w} / \mathrm{v})$ carboxymethylcellulose and $1.0 \%$ $(\mathrm{w} / \mathrm{v})$ maltodextrin were incorporated to enzymes solutions and the spray drier inlet temperature was $110^{\circ} \mathrm{C}$. Furthermore, this dried protease extracts showed potential for future commercial applications because of their stability at room temperature for 180 days.
\end{abstract}

Keywords: Bacillus; proteases; atomization; storage.

Practical Application: In this work, a durable protease-rich powder was obtained, allowing its use in future commercial applications.

\section{Introduction}

Proteases or peptidases constitute the class of enzymes with relevant role in a wide variety of industries, including leather, silk manufacturing, food and detergent industry (Freitas et al., 2012; Nasri et al., 2015; Singh \& Bajaj, 2017). Thermostable proteases produced from thermophilic bacteria are advantageous in industrial processes that operate at higher temperatures (Barbosa et al., 2014; Barzkar et al., 2018) and bacteria from the genus Bacillus are promising sources for thermostable proteases production (Saggu \& Mishra, 2017; Contesini et al., 2018; Zhou et al., 2020).

Bacillus sp. SMIA-2, a thermophilic and thermostable enzyme-producing bacterium was able to express a promising level of proteases in submerged cultures employing agricultural byproducts such as whey protein, corn steep liquor and passion fruit rind flour (Silva et al., 2007; Barbosa et al., 2014), which opened perspectives to generate high-value products from sustainable production processes. The bacterium was isolated from a soil sample collected in Campos dos Goytacazes City, Rio de Janeiro, Brazil. Phylogenetic analysis showed that this strain is a member of the Bacillus rRNA group 5 (Souza \& Martins, 2001). Recently, Bernardo et al. (2020) revealed that SMIA-2 is $100 \%$ identical with the type strain Bacillus licheniformis Gibson $46\left(\right.$ ATCC $\left.14580^{\mathrm{T}}\right)$. The characteristics presented by the protease produced by SMIA-2, such as ability to function at high temperatures and $\mathrm{pH}$ levels and resistant to several surfactants and oxidizing agents (Silva et al., 2007; Nascimento \& Martins, 2004) were very useful when thinking about industrial applications.

The performance of enzymes is influenced by its capacity for long term storage. Therefore, the development of formulations capable of preserving the activity of enzymes until their use is an important step in the manufacture of enzyme containing product (Costa-Silva et al., 2014). Spray drying is a cost-effective drying method widely used to stabilise heat sensitive ingredients, such as enzymes and probiotic bacteria (Schutyser et al., 2012; Assadpour \& Jafari, 2019; Bajaj et al., 2021). This technique has been extensively used for the dehydration of many industrial enzymes such as cellulases (Belghith et al., 2001; Libardi et al., 2020), alpha amylases (Samborska et al., 2005; Abdel-Mageed et al., 2019), lipases (Costa-Silva et al., 2014; Utami et al., 2017; Mohtar et al., 2019) and proteases (Namaldi et al., 2006; Cabral et al., 2017; Hamin et al., 2018). However, when subjected to the high temperatures used in the spray drying process, some enzymes may be denatured and, consequently, lose their catalytic activity 
(Hamin et al., 2014). A variety of excipients are often used as bulking agents and protective additives in an attempt to stabilize the enzymes (Ohtake et al., 2011; Emami et al., 2018).

In this work, the proteases recovered from SMIA-2 strain were spray-dried in the presence of adjuvants, and optimal conditions for preserving enzymatic activity were studied using a statistical experimental design.

\section{Material and methods}

\subsection{Microorganism and culture conditions}

The bacterial strain used in this study was a thermophilic Bacillus sp. previously isolated from a local soil sample. The culture medium for protease production contained $\left(\mathrm{gL}^{-1}\right)$ : $\mathrm{KCl}-0.3, \mathrm{MgSO}_{4}-0.5, \mathrm{~K}_{2} \mathrm{HPO}_{4}-0.87, \mathrm{CaCl}_{2}-0.29, \mathrm{ZnO}-2.03 \times 10^{-3}$, $\mathrm{FeCl}_{3} \cdot 6 \mathrm{H}_{2} \mathrm{O}-2.7 \times 10^{-2}, \mathrm{MnCl}_{2} .4 \mathrm{H}_{2} \mathrm{O}-1.0 \times 10^{-2}, \mathrm{CuCl}_{2} .2 \mathrm{H}_{2} \mathrm{O}-8.5 \times 10^{-4}$, $\mathrm{CoCl}_{2} \cdot 6 \mathrm{H}_{2} \mathrm{O}-2.4 \times 10^{-3}, \mathrm{NiCl}_{3} \cdot 6 \mathrm{H}_{2} \mathrm{O}-2.5 \times 10^{-4}, \mathrm{H}_{3} \mathrm{BO}_{3}-3.0 \times 10^{-4}$, commercial corn steep liquor (Sigma Aldrich) -3.0, whey protein-1.0 and soluble starch-5.0 (Corrêa et al., 2011).

The $\mathrm{pH}$ was adjusted to 7.2 with $1.0 \mathrm{M} \mathrm{NaOH}$ and the medium was sterilized by steam-autoclaving at $121^{\circ} \mathrm{C}, 1 \mathrm{~atm}$ for $15 \mathrm{~min}$. The medium (50 mL in $250 \mathrm{~mL}$ Erlenmeyer flasks) was inoculated with $1 \mathrm{~mL}$ of an standard overnight culture (initial number of cells $10^{4}$ ) and incubated at $50{ }^{\circ} \mathrm{C}$ in an orbital shaker (Thermo Forma, Ohio, USA) operated at $150 \mathrm{rpm}$. After $36 \mathrm{~h}$ of incubation culture, flasks were withdrawn and the contents were then centrifuged (HERMLEZ 382K, Wehingen, Germany) at $15,500 \mathrm{~g}$ for $15 \mathrm{~min}$, at $4^{\circ} \mathrm{C}$, and the cell free supernatant was used as used as crude enzyme preparation.

\subsection{Protease assay}

The activity of protease was assessed in triplicate by measuring the release of trichloroacetic-acid soluble peptides from $0.2 \%$ $(\mathrm{w} / \mathrm{v})$ azocasein prepared in $0.1 \mathrm{M}$ Tris/HCl buffer $(\mathrm{pH} 8.0)$.
The reaction mixture containing $0.5 \mathrm{~mL}$ of azocasein solution and $0.5 \mathrm{~mL}$ of appropriate concentration of enzyme solution was incubated at $70^{\circ} \mathrm{C}$ for $10 \mathrm{~min}$. The $1 \mathrm{~mL}$ reaction was terminated by the addition of $0.5 \mathrm{~mL}$ of $15 \%(\mathrm{w} / \mathrm{v})$ trichloroacetic acid and then centrifuged at 20,600 $\mathrm{g}$ for $5 \mathrm{~min}$, after cooling (Jenssen et al., 1994). The absorbance of the non-precipitable azopeptides produced as a result of the protease activity was measured at $420 \mathrm{nM}$ and corrected using a reagent blank. One unit (U) of enzyme activity was defined as the amount of enzyme required to produce an increase in absorbance at $420 \mathrm{nM}$ equal to $1.0 \mathrm{in}$ 60 minutes.

\subsection{Spray drying of crude enzyme solution}

Spray-dried powders were produced through the atomization of crude proteases preparation in a lab-scale spray dryer (LABPLANT, MODEL SD-04, England). During operation, $100 \mathrm{~mL}$ prepared solution was fed at constant rate, $5.40 \mathrm{~mL} / \mathrm{min}$ with a peristaltic pump to a nozzle, where atomization occurred by means of a pressurized air stream. Drying air entered the drying chamber in the same direction as the descending spray droplets. The process variable was the drier air inlet temperature and the adjuvants concentrations as showed in Table 1. According to the working inlet temperatures $70,86,110,134$ and $150^{\circ} \mathrm{C}$, observed drier outlet temperatures were 52, 65, 76, 92 and $102{ }^{\circ} \mathrm{C}$, respectively.

In all of the experiments the air flow rate was constant. The adjuvants were incorporated into the enzyme solution before spray drying. The dried particles were collected and stored at room temperature $\left(25-32{ }^{\circ} \mathrm{C}\right)$.

The protease activity was measured before and after drying. The activity measurement of the proteases after drying operation was accomplished by dissolving enzymes powder $\left(0.01 \mathrm{~g} \cdot \mathrm{mL}^{-1}\right)$ and the residual activity (\%) determined and compared with the activity of the crude enzyme solution before drying.

Table 1. Matrix of CCD $2^{3}$ (real and coded values) used and their responses.

\begin{tabular}{|c|c|c|c|c|c|}
\hline Experiment number & $\begin{array}{l}\text { Inlet air temperature } \\
\qquad\left({ }^{\circ} \mathrm{C}\right)\end{array}$ & $\mathrm{CMC}(\%, \mathrm{w} / \mathrm{v})$ & $\operatorname{MD}(\%, w / v)$ & Mass recovery (\%) & $\begin{array}{c}\text { Residual protease } \\
\text { activity (\%) }\end{array}$ \\
\hline 1 & $86(-1)$ & $0.32(-1)$ & $1.6(-1)$ & 15.06 & 78.58 \\
\hline 2 & $134(+1)$ & $0.32(-1)$ & $1.6(-1)$ & 19.60 & 85.23 \\
\hline 3 & $86(-1)$ & $0.68(+1)$ & $1.6(-1)$ & 19.15 & 80.32 \\
\hline 4 & $134(+1)$ & $0.68(+1)$ & $1.6(-1)$ & 23.38 & 81.91 \\
\hline 5 & $86(-1)$ & $0.32(-1)$ & $3.4(+1)$ & 20.67 & 67.80 \\
\hline 6 & $134(+1)$ & $0.32(-1)$ & $3.4(+1)$ & 26.20 & 74.67 \\
\hline 7 & $86(-1)$ & $0.68(+1)$ & $3.4(+1)$ & 17.51 & 64.69 \\
\hline 8 & $134(+1)$ & $0.68(+1)$ & $3.4(+1)$ & 19.72 & 63.10 \\
\hline 9 & $70(-1.68)$ & $0.5(0)$ & $2.5(0)$ & 16.72 & 76.99 \\
\hline 10 & $150(+1.68)$ & $0.5(0)$ & $2.5(0)$ & 23.37 & 74.24 \\
\hline 11 & $110(0)$ & $0.1(-1.68)$ & $2.5(0)$ & 19.61 & 79.88 \\
\hline 12 & $110(0)$ & $0.8(+1.68)$ & $2.5(0)$ & 22.01 & 76.70 \\
\hline 13 & $110(0)$ & $0.5(0)$ & $1(-1.68)$ & 17.54 & 86.69 \\
\hline 14 & $110(0)$ & $0.5(0)$ & $4(+1.68)$ & 27.49 & 72.94 \\
\hline 15 & $110(0)$ & $0.5(0)$ & $2.5(0)$ & 16.73 & 80.82 \\
\hline 16 & $110(0)$ & $0.5(0)$ & $2.5(0)$ & 17.46 & 79.45 \\
\hline 17 & $110(0)$ & $0.5(0)$ & $2.5(0)$ & 17.66 & 80.03 \\
\hline
\end{tabular}




\subsection{Experimental design and statistical analysis}

A central composite design (CCD) $2^{3}$ was constructed to evaluate the effects of the adjuvants concentrations and spray drier inlet air temperature on Residual protease activity and Mass recovery of the powder. The factorial planning encompassed three central points and yielded a total of 17 treatments for each experiment. The factors and factors levels studied are described in Table 1.

The results obtained were submitted to a regression analysis, initially calculating a polynomial equation, evaluating its lack of adjustment and the significance of each variable at $p<0.05$. The predictive model was adjusted considering only the significant parameters and response surface graphs were drawn for those models with a high correlation coefficient, using the Statistica software, version 7.0.

Condition optimization was performed using CCD, and response surface was produced with fixed central points of $110^{\circ} \mathrm{C}$ to inlet air temperature, $0.5 \%(\mathrm{w} / \mathrm{v}) \mathrm{CMC}$ and $2.5 \%(\mathrm{w} / \mathrm{v})$ maltodextrin. The model of the experiment can be expressed as follows (Equation 1):

$Y=b_{o}+\sum_{i=1}^{n} b_{i} x_{i}+\sum_{i=1}^{n} b_{i i} x_{i}^{2}+\sum_{i \neq j=1} \sum b_{i j} x_{i} x_{j}$

Where $b o, b i, b i i$ and $b i j$ are the intercept terms, linear, quadratic coefficient and interactive coefficient, respectively, and $x i$ and $x j$ are coded independent variables.

\subsection{Mass recovery (\%)}

The mass recovery was determined according to Belghith et al. (2001) (Equation 2).

$$
\text { Mass recovery }(\%)=\frac{\mathrm{Wt}}{\mathrm{TSS}} \times 100
$$

Where, TSS is the total soluble solid of the crude protease solution in the presence of the adjuvant and $\mathrm{Wt}$ is the weight of powder mass ( $\mathrm{g}$ ) obtained from spray-drying process. TSS was determined from the crude extract protease solution using a hand-held digital refractometer (Pocket Refractometer Pal-1, Atago Co. Ltd, Tokyo, Japan). Three measurements were recorded from each sample.

\subsection{Proteases powder stability (\%)}

After drying, storage stability of obtained proteases powders at room temperature $\left(25-32{ }^{\circ} \mathrm{C}\right)$ up to 180 days was investigated. The stability of protease was determined by measuring protease activities right after drying and after six months of storage.

\subsection{Water activity (aw)}

The water activity was determined in the dried samples by direct reading in an apparatus (water activity meter, HygroLab C1 Bench-Top Indicator, Rotronic AG, Switzerland).

\section{Results and discussion}

Considering the great industrial relevance of thermostable proteases produced by Bacillus sp SMIA-2, an attempt was done to increase their shelf life by using the spray drying process. The proteases were recovered from 36 hours of Bacillus sp SMIA-2 submerged cultures containing pectin, corn steep liquor and whey protein. The proteases were not purified before spray drying process because of their high cost. Besides, during the purification process ligand and/or proteins that have a protective effect on the crude enzyme could be removed and consequently, the enzyme properties could modify in such way that their kinetic and thermodynamic behaviour could also be different (Braga et al., 2013). Thus, the crude protease extract (13.82 $\mathrm{UmL}^{-1}$ ) containing by-products of the fermentation process (other proteins, carbohydrates and salts) was subjected to spray drying process, in order to develop stable formulations of the dry enzyme.

It is known that an enzyme functions best at a certain temperature. According to Silva et al. (2007), the optimum temperature for activity of protease from Bacillus sp SMIA-2 was $70{ }^{\circ} \mathrm{C}$ and the enzyme retained $80 \%$ of the original activity after $2 \mathrm{~h}$ heat treatment at $60^{\circ} \mathrm{C}$. An alternative to avoid loss of protease activity would be to use lower temperatures in the drying process. However, the use of low temperatures can lead to a reduction in the production rate and generate a product with higher moisture content and with low storage stability. The addition of excipients to the enzyme crude solution prior to spray drying process is another alternative usually taken for this purpose. Thus, carboxymethylcellulose and maltodextrin were incorporated into the enzyme solution before spray drying and the interactive effect between them and the inlet air temperature $\left({ }^{\circ} \mathrm{C}\right)$ were studied using a central composite design (CCD) $2^{3}$. Factor levels (inlet air temperatures and both maltodextrin and CMC concentrations) were chosen based on studies published in the literature focused on protease spray drying (Namaldi et al., 2006; Hamin et al., 2017) and in preliminary experiments. Table 1 shows the results of the Residual protease activity and Mass recovery of powder obtained, according to the experimental planning carried out.

The Residual protease activity values varied from $63.1 \%$ to $86.69 \%$. In this case, the best result (Formulation 13) was obtained when $0.5 \%(\mathrm{w} / \mathrm{v}) \mathrm{CMC}$ and $1.0 \%(\mathrm{w} / \mathrm{v}) \mathrm{MD}$ were incorporated to enzymes solutions and the spray drier inlet temperature was $110^{\circ} \mathrm{C}$. There are several studies of adding carbohydrates to enzymes containing formulations. The effect of air inlet temperature of the spray dryer between $70^{\circ} \mathrm{C}$ and $130^{\circ} \mathrm{C}$ and the effect of protective additives, glucose and maltodextrin, at $0-2 \%(\mathrm{w} / \mathrm{v})$ on protease activity produced by recombinant Bacillus subtilis (BGSC-1A751) during spray drying were evaluated by Namaldi et al. (2006). Also, Hamin et al. (2018) evaluated the best conditions to remove the water by spray drying technique from collagenolytic proteases from Myceliophthora thermophila submerged bioprocess and Siqueira et al. (2013) selected the adequate adjuvant and evaluated the best parameters to use in drying the Trichoderma harzianum enzymatic extract containing peptidases and cellulases. According to all these authors higher activity preservation was obtained when the additives 
were incorporated before spray drying the formulations and that the degree of improvement was dependent on the nature of the carbohydrate and its concentration.

No powder was recovered when the crude extract rich in proteases was dried in the absence of additives. The filtration of the fermented broth previously to the spray drying process, probably reduced the solids concentration. In fact, the culture supernatant generally contains very low amount of solids leading to high drying cost per unit weight of the product formed with very low product recoveries (Gupta et al., 2014). Therefore, the use of excipients is justified not only to avoid thermal denaturation leading to loss of enzyme activity (Silva et al., 2007; Piszkiewicz \& Pielak, 2019; Giovannelli et al., 2021), but also to develop more stable enzyme formulations and to improve dry mass recovery purposes (Libardi et al., 2020).

As can be observed in Table 1, the maximum percentage of mass recovered obtained was about 27\% (Essay 14). The low mass recovery may be related to the powder collector system performance (cyclone) used in the equipment. This problem could be solved during the scaling-up process, by choosing a more efficient collecting system (Costa-Silva et al., 2014).

An analysis of variance was performed for the experimental results presented in Table 1 in order to identify the variables that showed statistical significance. In this context, the results illustrated in the Pareto graph (Figure 1) revealed a negative, but statistically significant, influence of the three independent variables on Residual protease activity at the $95 \%$ confidence level. Increased concentrations of MD, CMC and inlet air temperature reduced protease activity. The concentration of maltodextrin was the variable that, originally presented a comparatively more pronounced effect (Figure 1A). On the other hand, increased inlet air temperature and increased MD concentration promoted a better mass recovery (Figure 1B). Thus, the conditions that led to higher levels of protease activity were different from those that provided the greatest Mass recovery.

Regression analysis was applied to the experimental results of the Residual protease activity and the Mass recovered. First, a model containing all linear and quadratic effects, as well as the interaction factors between the variables, was tested.
Table 2 shows the results of Anova and Regression coefficient of the adjusted model.

The adjusted models were highly significant $(\mathrm{p}<0.05)$, with a satisfactory value of determination coefficient $\left(\mathrm{R}^{2}\right)$. It was possible to state that $85.40 \%$ and $86.64 \%$ of the variability in the Residual protease activity (\%) and Mass Recovered (\%) response respectively, could be accounted by the model and that it was suitable to represent the real relationship among the independent variables studied. When the calculated $\mathrm{F}$ value is greater than the table for the adopted confidence level, there is sufficient statistical

(A)

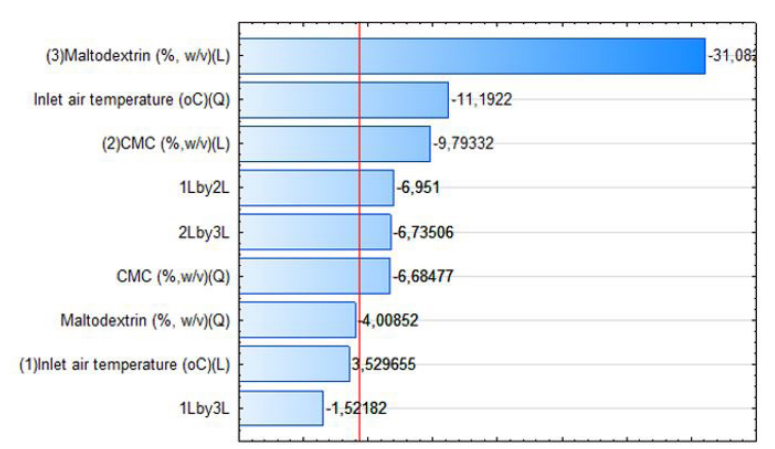

(B)

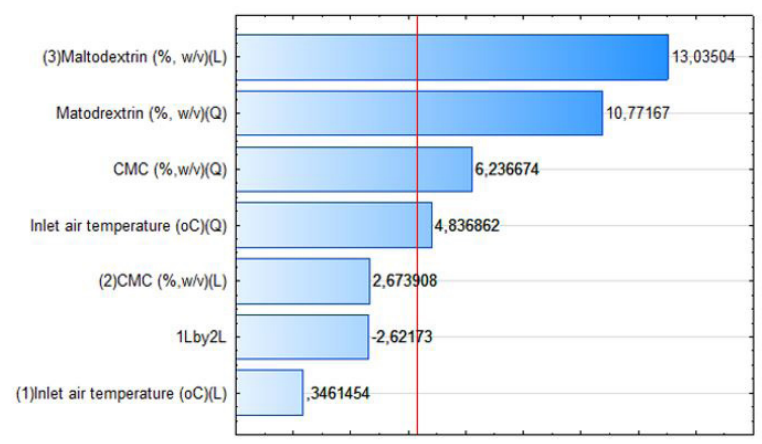

Figure 1. Effect of the studied independent variables and their interactions: (A) Residual protease activity (\%); (B) Mass recovery, for a $95 \%$ confidence level $(\mathrm{p}<0.05)$.

Table 2. ANOVA for the variables of response surface quadratic model.

\begin{tabular}{|c|c|c|c|c|c|c|}
\hline Variable & Sum of squares & (Degrees of freedom) & Mean square & Fcal. & Ftab0.05 & $\mathrm{P}<0.05$ \\
\hline \multicolumn{7}{|l|}{ Residual activity (\%) } \\
\hline Regression & 602.2879 & 2 & 301.1440 & 41.1112 & 3.74 & 0.000689 \\
\hline Residues & 102.5514 & 14 & 7.3251 & & & \\
\hline Lack of adjustement & 101.6056 & 12 & 8.4671 & 17.9047 & 19.41 & \\
\hline Pure error & 0.9458 & 2 & 0.4729 & & & \\
\hline Total error & 694.8852 & 16 & 43.4303 & & & \\
\hline \multicolumn{7}{|l|}{ Mass recovery (\%) } \\
\hline Regression & 180.2790 & 2 & 90.1395 & 48.9591 & 3.74 & 0.000438 \\
\hline Residues & 25.7756 & 14 & 1.8411 & & & \\
\hline Lack of adjustement & 25.2964 & 12 & 2.1080 & 8.7969 & 19.41 & \\
\hline Pure error & 0.4793 & 2 & 0.2396 & & & \\
\hline Total error & 192.9564 & 16 & 12.0598 & & & \\
\hline
\end{tabular}


evidence to suppose the existence of a relationship between the variables. The lack of adjustment was not significant $\left(\mathrm{F}_{\mathrm{cal}}\right.$ less than the $\left.\mathrm{F}_{\mathrm{tab}}\right)$, indicating that the experimental data adjusted to the obtained models.

Subsequently, in order to conduct a comprehensive study of the influence of the independent variables on the Residual protease activity and Mass recovered of the powder, experimental and predicted values were compared with empirical equations adjusted with base on the analysis of variance (ANOVA). The equations obtained to predict the Residual activity of the protease (Equation 3) and the Mass recovered (Equation 4) of the obtained powder are:

$\%$ Residual activity $=79.261-2.062 X_{1}^{2}-1.582 X_{2}-1.116 X_{2}^{2}-5.778 X_{3}-1.690 X_{1} X_{2}-1.637 X_{2} \cdot X^{3}$

$\%$ Mass recovery $=17.360+2.028 X_{1}+0.711 X_{1}^{2}+0.981 X_{2}^{2}+1.731 X_{3}+1.584 X_{3}^{2}-2.189 X_{2} \cdot X_{3}$

Where $x_{1}$ is the Temperature $\left({ }^{\circ} \mathrm{C}\right), x_{2}$ is the MD and $x_{3}$ is the CMC concentration $(\%, \mathrm{w} / \mathrm{v})$.
The response surface and contour plot graphs (Figure 2) showed a relationship between two variables at time. The non-explicit variables were fixed at the central point (level 0 ) for the surface construction. An initial increase in CMC concentration in combination with lower concentrations of maltodextrin $(<1.75 \%$; $/ \mathrm{v})$ resulted in an increase of Residual protease activity (Figure 2A). In addition, it was observed that higher values of Mass recovery were found when higher concentrations of maltodextrin in combination with lower CMC concentrations were incorporated to enzyme solution. However, when lower concentrations of maltodextrin were combined with higher concentrations of $\mathrm{CMC}$, higher values were also found (Figure 2D). As showed in Figure 2B, inlet air temperatures between $110-140{ }^{\circ} \mathrm{C}$ and $\mathrm{CMC}$ concentrations lower than $0.45 \%(\mathrm{w} / \mathrm{v})$ resulted in higher Residual protease activity. The Mass recovery increased with increasing the inlet air temperatures within the experimental level at both high and low concentrations of CMC (Figure 2E). Higher inlet air temperatures and maltodextrin concentrations lower than $1.75 \%$
(A)

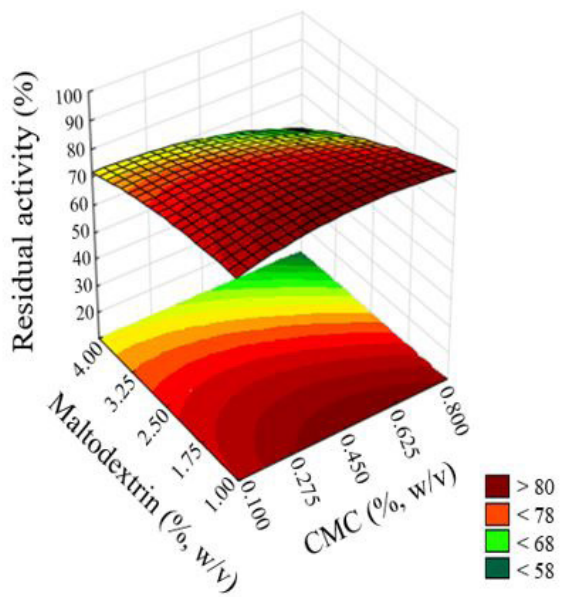

(D)

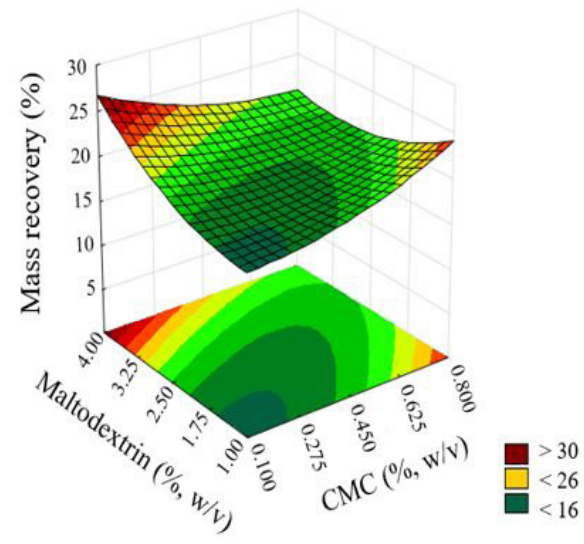

(B)

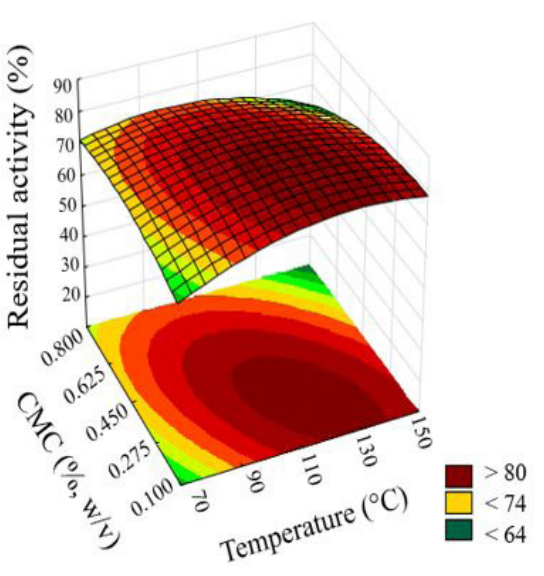

(E)



(C)



(F)

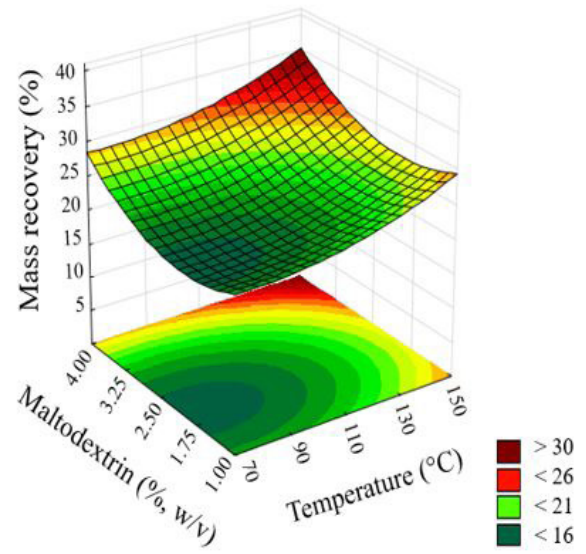

Figure 2. Three-dimensional response surface plot for: Effect of maltodextrin and CMC concentration on Residual protease activity (A) and Mass recovery (D) at a constant spray drier inlet temperature; Effect of spray drier inlet temperature and CMC concentration on Residual protease activity (B) and Mass recovery (E) at a constant maltodextrin concentration; Effect of spray drier inlet temperature and maltodextrin concentration on Residual protease activity $(\mathrm{C})$ and Mass recovery $(\mathrm{F})$ at a constant CMC concentration. Dark red color indicates high Residual protease activity and Mass recovery, while green and yellow color indicates low Residual protease activity and Mass recovery. 




Figure 3. Effect of six months of storage on the protease stability ( $\square$ ) and the water activity ( - ) of the powder.

$(\mathrm{w} / \mathrm{v})$ resulted in higher Residual protease activity (Figure 2C). Furthermore, high inlet air temperatures combined with high maltodextrin concentrations resulted in greater mass recovery (Figure 2F). Thus, the experimental design approach used in this study was found to be effective in rapidly assessing the spray drying conditions for obtaining protease powder at any point within the range of inlet air temperature and concentration of both CMC and maltodextrin tested.

\subsection{Protease powder stability}

The stability of obtained proteases powders formulations during storage at room temperature for six months was investigated. The highest enzyme stability was maintained (80\%) after 180 days for the Formulation 13, that was dried with $0.5 \%$ $\mathrm{CMC}$ and $1.0 \% \mathrm{MD}$ and spray drier inlet temperature of $110^{\circ} \mathrm{C}$ (Figure 3). Under this condition, satisfactory levels of protease activity were found.

The water activity (aw) of the proteases dried formulations are also showed in Figure 3. Values below 0.6 were obtained for all formulations, indicating their potential for storage. The values of aw could indicate the possibility of microorganism growth and toxin production. According to Beuchat (1981) water activity values above 0.6 could promote microorganism growth and above 0.8 facilitate toxin production.

\section{Conclusion}

The study showed that the spray drying process used in this work was effective to dehydrate the proteases recovered from the submerged cultures of Bacillus sp. SMIA-2, maintaining good enzymatic activity when storage at room temperature for 180 days. The spray-dried protease generated could be very useful for industrial applications such as in the detergent industry, that not require the enzyme in pure form.

\section{References}

Abdel-Mageed, H. M., Fouad, S. A., Teaima, M. H., Abdel-Aty, A. M., Fahmy, A. S., Shaker, D. S., \& Mohamed, S. A. (2019). Optimization of nano spray drying parameters for production of $\alpha$-amylase nanopowder for biotheraputic applications using factorial design. Drying Technology, 37(16), 2152-2160. http://dx.doi.org/10 $.1080 / 07373937.2019 .1565576$.

Assadpour, E., \& Jafari, S. M. (2019). Advances in spray-drying encapsulation of food bioactive ingredients: from microcapsules to nanocapsules. Annual Review of Food Science and Technology, 10(1), 103-131. http://dx.doi.org/10.1146/annurev-food-032818-121641. PMid:30649963.

Bajaj, S. R., Marathe, S. J., \& Singhal, R. S. (2021). Co-encapsulation of vitamins B12 and D3 using spray drying: wall material optimization, product characterization, and release kinetics. Food Chemistry, 335, 127642. http://dx.doi.org/10.1016/j.foodchem.2020.127642. PMid:32739814.

Barbosa, J. B., Gentil, N. O., Ladeira, S. A., \& Martins, M. L. L. (2014). Cheese whey and passion fruit rind flour as substrates for protease production by Bacillus sp. SMIA-2 strain isolated from Brazilian soil. Biocatalysis and Biotransformation, 32(4), 244-250. http://dx.doi.or g/10.3109/10242422.2014.934363.

Barzkar, N., Homaei, A., Hemmati, R., \& Patel, S. (2018). Thermostable marine microbial proteases for industrial applications: scopes and risks. Extremophiles, 22(3), 335-346. http://dx.doi.org/10.1007/ s00792-018-1009-8. PMid:29442247.

Belghith, H., Chaabouni, S. E., \& Gargouri, A. (2001). Stabilization of Penicillium occitanis cellulases by spray drying in presence of maltodextrin. Enzyme and Microbial Technology, 28(2-3), 253-258. http://dx.doi.org/10.1016/S0141-0229(00)00322-7. PMid:11166820.

Bernardo, S. P. C., Rosana, A. R. R., Souza, A. N., Chiorean, S., Martins, M. L. L., \& Vederas, J. C. (2020). Draft genome sequence of the thermophilic bacterium Bacillus licheniformis SMIA-2, an antimicrobial-and thermostable enzyme-producing isolate from Brazilian soil. Microbiology Resource Announcements, 9(17). http:// dx.doi.org/10.1128/MRA.00106-20. PMid:32327520.

Beuchat, L. R. (1981). Microbial stability as affected by water activity. Cereal Foods World, 26(7), 345-349.

Braga, A. R. C., Manera, A. P., Ores, J., Sala, L., Maugerim, F., \& Kalil, S. J. (2013). Kinetics and thermal properties of crude and purified $\beta$-galactosidase with potential for the production of galactooligosaccharides. Food Technology and Biotechnology, 51(1), 45-52.

Cabral, T. P. F., Bellini, N. C., Assis, K. R., Teixeira, C. C. C., Lanchote, A. D., Cabral, H., \& Freitas, L. A. P. (2017). Microencapsulate Aspergillus niger peptidases from agroindustrial waste wheat bran: spray process evaluation and stability. Journal of Microencapsulation, 34(6), 560-570.

Contesini, F. J., Melo, R. R. D., \& Sato, H. H. (2018). An overview of Bacillus proteases: from production to application. Critical Reviews in Biotechnology, 38(3), 321-334. http://dx.doi.org/10.1080/073885 51.2017.1354354. PMid:28789570.

Corrêa, T. L. R., Moutinho, S. K. D. S., Martins, M. L. L., \& Martins, M. A. (2011). Simultaneous $\alpha$-amylase and protease production by the soil bacterium Bacillus sp. SMIA-2 under submerged culture using whey protein concentrate and corn steep liquor: compatibility of enzymes with commercial detergents. Food Science and Technology, 31(4), 843-848. http://dx.doi.org/10.1590/S0101-20612011000400003.

Costa-Silva, T. A., Souza, C. R. F., Oliveira, W. P., \& Said, S. (2014). Characterization and spray drying of lipase produced by the endophytic fungus Cercospora kikuchii. Brazilian Journal of Chemical Engineering, 31(4), 849-858. http://dx.doi.org/10.1590/01046632.20140314s00002880.

Emami, F., Vatanara, A., Park, E. J., \& Na, D. H. (2018). Drying technologies for the stability and bioavailability of biopharmaceuticals. Pharmaceutics, 10(3), 131. 
Freitas, A. C. V. Jr, Costa, H. M. S., Icimoto, M. Y., Hirata, I. Y., Marcondes, M., Carvalho, L. B. Jr, Oliveira, V., \& Bezerra, R. (2012). Giant Amazonian fish pirarucu (Arapaima gigas): its viscera as a source of thermostable trypsin. Food Chemistry, 133(4), 1596-1602. http://dx.doi.org/10.1016/j.foodchem.2012.02.056.

Giovannelli, L., Milanesi, A., Ugazio, E., Fracchia, L., \& Segale, L. (2021). Effect of methyl- $\beta$-cyclodextrin and trehalose on the freeze-drying and spray-drying of sericin for cosmetic purposes. Pharmaceuticals, 14(3), 262. http://dx.doi.org/10.3390/ph14030262. PMid:33803976.

Gupta, G., Sahai, V., Mishra, S., \& Gupta, R. K. (2014). Spray-drying of xylanase from thermophilic fungus Melanocarpus albomyces effect of carriers and binders on enzyme stability. Indian Journal of Chemical Technology, 21, 89-95.

Hamin, Y. A. A. No, Coitinho, L. B., Freitas, L. A. P., \& Cabral, H. (2017). Box-Behnken analysis and storage of spray-dried collagenolytic proteases from Myceliophthora thermophila submerged bioprocess. Preparative Biochemistry \& Biotechnology, 47(5), 473-480. http:// dx.doi.org/10.1080/10826068.2017.1292289. PMid:28278111.

Hamin, Y. A. A. No, Freitas, L. A. P., Cabral, H. (2014). Multivariate analysis of the stability of spray-dried Eupenicillium javanicum peptidases. Drying Technology, 32(5), 614-621.

Hamin, Y. A. A. No, Garzon, N. G. R., Pedezzi, R., \& Cabral, H. (2018). Specificity of peptidases secreted by filamentous fungi. Bioengineered, 9(1), 30-37.

Jenssen, P. H., Peek, K., \& Morgan, H. W. (1994). Effect of culture conditions on the production of an extracellular proteinase by Thermus sp. Rt41A. Applied Microbiology and Biotechnology, 41(4), 400-406. http://dx.doi.org/10.1007/BF00212249.

Libardi, N., Soccol, C. R., Tanobe, V. O., \& Vandenberghe, L. P. S. (2020). Definition of liquid and powder cellulase formulations using domestic wastewater in bubble column reactor. Applied Biochemistry and Biotechnology, 190(1), 113-128. http://dx.doi.org/10.1007/ s12010-019-03075-1. PMid:31301011.

Mohtar, N. S., Rahman, M. B. A., Mustafa, S., Ali, M. S. M., \& Rahman, R. R. A. (2019). Spray-dried immobilized lipase from Geobacillus sp. strain ARM in sago. PeerJ, 7, e6880. http://dx.doi.org/10.7717/ peerj.6880. PMid:31183251.

Namaldi, A., Çalik, P., \& Uludag, Y. (2006). Effects of spray drying temperature and additives on the stability of serine alkaline protease powders. Drying Technology, 24(11), 1495-1500. http://dx.doi. org/10.1080/07373930600961108.

Nascimento, W. C. A., \& Martins, M. L. L. (2004). Production and properties of an extracellular protease from thermophilic Bacillus sp. Brazilian Journal of Microbiology, 35(1-2), 91-96. http://dx.doi. org/10.1590/S1517-83822004000100015.

Nasri, R., Abed, H., Karra-châabouni, M., Nasri, M., \& Bougatef, A. (2015). Digestive alkaline proteases from Serranus scriba viscera: characteristics, application in the extraction of carotenoproteins from shrimp waste, and evaluation in laundry commercial detergents. Biocatalysis and Agricultural Biotechnology, 4(3), 355-361. http:// dx.doi.org/10.1016/j.bcab.2015.05.001.

Ohtake, S., Kita, Y., \& Arakawa, T. (2011). Interactions of formulation excipients with proteins in solution and in the dried state. Advanced Drug Delivery Reviews, 63(13), 1053-1073. http://dx.doi.org/10.1016/j. addr.2011.06.011. PMid:21756953.

Piszkiewicz, S., \& Pielak, G. J. (2019). Protecting enzymes from stressinduced inactivation. Biochemistry, 58(37), 3825-3833.

Saggu, S. K., \& Mishra, P. C. (2017). Characterization of thermostable alkaline proteases from Bacillus infantis SKS1 isolated from garden soil. PLoS One, 12(11), e0188724. http://dx.doi.org/10.1371/journal. pone.0188724. PMid:29190780.

Samborska, K., Witrowa-Rajchert, D., \& Gonçalves, A. (2005). Spraydrying of $a$-amylase - the effect of process variables on the enzyme inactivation. Drying Technology, 23, 941-953.

Schutyser, M. A., Perdana, J., \& Boom, R. M. (2012). Single droplet drying for optimal spray drying of enzymes and probiotics. Trends in Food Science \& Technology, 27(2), 73-82. http://dx.doi.org/10.1016/j. tifs.2012.05.006.

Silva, C. R. D., Delatorre, A. B., \& Martins, M. L. L. (2007). Effect of the culture conditions on the production of an extracellular protease by thermophilic Bacillus sp. and some properties of the enzymatic activity. Brazilian Journal of Microbiology, 38(2), 253-258. http:// dx.doi.org/10.1590/S1517-83822007000200012.

Singh, S., \& Bajaj, B. K. (2017). Potential application spectrum of microbial proteases for clean and green industrial production. Energy, Ecology \& Environment, 2(6), 370-386. http://dx.doi.org/10.1007/ s40974-017-0076-5.

Siqueira, A. N. R., Rosa, N. G., Bastos, P. No, Rodrigues, A., Freitas, L. A. P., \& Cabral, H. (2013). Optimization of the drying parameters for an enzymatic extract, and an evaluation of the subsequent proteolytic and cellulolytic activities. Biochemistry and Biotecnology Reports. Biochemistry and Biotechnology Reports, 2(1), 17-24.

Souza, A. N. D., \& Martins, M. L. L. (2001). Isolation, properties and kinetics of growth of a thermophilic Bacillus. Brazilian Journal of Microbiology, 32(4), 271-275. http://dx.doi.org/10.1590/S151783822001000400003 .

Utami, T. S., Hariyani, I., Alamsyah, G., \& Hermansyah, H. (2017). Production of dry extract extracellular lipase from Aspergillus niger by solid state fermentation method to catalyze biodiesel synthesis. Energy Procedia, 136, 41-46. http://dx.doi.org/10.1016/j. egypro.2017.10.275.

Zhou, C., Zhou, H., Li, D., Zhang, H., Wang, H., \& Lu, F. (2020). Optimized expression and enhanced production of alkaline protease by genetically modified Bacillus licheniformis 2709. Microbial Cell Factories, 19(1), 45. http://dx.doi.org/10.1186/s12934-020-01307-2. PMid:32093734. 